\title{
A single nucleotide mutation drastically increases the expression of tumor-homing NGR-TNFa in the E. coli M15-pQE30 system by improving gene transcription
}

\author{
Jie Chen ${ }^{1} \cdot$ Hao Yang ${ }^{1,2,3} \cdot$ Yanru Feng ${ }^{1} \cdot$ Qiuxiao Shi ${ }^{1} \cdot{\text { Zhao } \mathrm{Li}^{1} \cdot \text { Ze Tao }^{1} \cdot \text { Jie Fan }}^{1} \cdot$ Youmei Jin ${ }^{1} \cdot$ Shengfu Li ${ }^{1}$. \\ Jingqiu Cheng ${ }^{1,2} \cdot$ Xiaofeng $\mathrm{Lu}^{1,2,3}$ (D)
}

Received: 28 September 2020 / Revised: 12 January 2021 / Accepted: 20 January 2021 / Published online: 2 February 2021

(C) The Author(s), under exclusive licence to Springer-Verlag GmbH, DE part of Springer Nature 2021

\begin{abstract}
Due to their potent immune stimulation, tumor necrosis factor alpha (TNF $\alpha$ ) variants with tumor-homing activity are attractive as novel antitumor drugs. The promising antitumor effect of NGR-TNF $\alpha$ in clinical trials triggered extensive interest in developing novel tumor-homing TNF $\alpha$ variants in recent years. Owing to its promising antitumor effect, NGR-TNF $\alpha$ is usually used as a control for newly developed tumor-homing TNF $\alpha$ variants. In our previous works, we produced a pericyte-targeting Z-TNF $\alpha$ at high levels using the Escherichia coli (E. coli) M15-pQE30 system. To further compare Z-TNF $\alpha$ and NGR-TNF $\alpha$, we attempted to express NGR-TNF $\alpha$ using the same system. Surprisingly, native NGR-TNF $\alpha$ was expressed at a low $(\sim 0.2 \mathrm{mg} / \mathrm{L})$ level in E. coli $\mathrm{M} 15$ containing the $\mathrm{pQE} 30$ plasmid. However, a single nucleotide mutation of $\mathrm{C}$ to $\mathrm{G}$, resulting in a substitution of leucine (L) with valine $(\mathrm{V})$ at the start of TNF $\alpha$, increased the expression of NGR-TNF $\alpha$ by $\sim 100$ times through improving transcription. In addition, the amino acid substitution showed a little impact on the receptor binding, in vitro cytotoxicity, and in vivo antitumor effect of NGR-TNF $\alpha$. As fusing NGR to the N-terminus of TNF $\alpha$ with a valine substitution did not reduce the protein yield, the $\mathrm{TNF} \alpha$ gene with a $\mathrm{C}>\mathrm{G}$ mutation might be used to prepare novel tumor-homing TNF $\alpha$ when the native TNF $\alpha$-based variant is expressed at an extremely low level in E. coli. Notably, in addition to the mutated valine, the impact of N-terminal additional amino acids provided by $\mathrm{pQE} 30$ vector on the function of $\mathrm{TNF} \alpha$ variant must be carefully evaluated.
\end{abstract}

\section{Key points}

- A single nucleotide mutation increased the expression of NGR-TNF $\alpha$ by two orders.

- Nucleotide mutation-induced amino acid substitution did not reduce NGR-TNFo activity.

Keywords Tumor necrosis factor alpha $\cdot$ Tumor vasculature normalization $\cdot$ Nucleotide mutation $\cdot$ Recombinant expression . Escherichia coli

Jie Chen and Hao Yang contributed equally to this work.

Jingqiu Cheng

jqcheng@scu.edu.cn

$\triangle$ Xiaofeng Lu

xiaofenglu@scu.edu.cn

1 Key Lab of Transplant Engineering and Immunology, $\mathrm{MOH}$, Regenerative Medical Research Center, West China Hospital, Sichuan University, Chengdu 610041, China

2 Frontiers Science Center for Disease-related Molecular Network, Chengdu 610041, China

3 Sichuan Provincial Engineering Laboratory of Pathology in Clinical Application, Chengdu 610041, China

\section{Introduction}

Excessive angiogenesis is a pivotal characteristic in the tumor microenvironment to fuel malignant tumor growth and metastasis. To obtain sufficient oxygen and nutrients, overgrowing tumor cells frequently release pro-angiogenesis factors, which results in the formation of disorganized blood vessel networks in solid tumors (Lugano et al. 2020; Zuazo-Gaztelu and Casanovas 2018). Aberrant architecture, including dilation, tortuosity, and inadequate perivascular cell investment of the disorganized tumor vascular system, induce high permeability of tumor blood vessels, which further induces elevated interstitial fluid pressure, thus causing poor perfusion of antitumor agents into the tumor parenchyma (Viallard and Larrivee 
2017; Yehya et al. 2018). Selective destruction of the tumor vasculature to increase vessel permeability is a conventional strategy for antitumor agent delivery (Hong et al. 2020; Siemann 2011). Compared to vasculature disruption, vessel normalization has been found to be more efficient at improving the blood perfusion and tumor-targeted delivery of antitumor agents (Huang et al. 2018; Viallard and Larrivee 2017). In fact, anti-angiogenesis mediated by vascular endothelial growth factor (VEGF)-neutralizing antibodies or VEGF receptor blockers makes the tumor blood vessels more similar to normal blood vessels in structure and function, an observation designated as vessel normalization. Compared to disorganized tumor blood vessels, these normalized tumor blood vessels exert better blood perfusion and drug delivery, and this has led to a rapid progress in combining vessel normalization inducers and chemicals or radioactive substances for the treatment of solid tumors in recent years (Fan et al. 2019; Ho et al. 2019; Park et al. 2017).

Tumor necrosis factor alpha $(\mathrm{TNF} \alpha)$ is a homotrimeric cytokine exerting potent antitumor activities by binding to its cell surface receptors TNFR1 and TNFR2. However, owing to its life-threatening systemic toxicity, recombinant $\mathrm{TNF} \alpha$ is only approved in Europe to treat patients with limb-threatening soft tissue sarcoma via local perfusion (Balkwill 2009; Jakob and Hohenberger 2016). To reduce systemic toxicity, ligands recognizing tumor-associated endothelial cells or pericytes have been genetically conjugated to $\mathrm{TNF} \alpha$ (Curnis et al. 2000; Fan et al. 2019; Johansson et al. 2012). Of these fusion proteins, NGR-TNF $\alpha$ was constructed by coupling the tumor-homing NGR peptide to TNF $\alpha$. In addition to disrupting tumors at high doses, NGR-TNF $\alpha$ was found to induce vessel normalization by modulating endothelial cells at low doses, which facilitated the tumortargeted delivery of chemotherapeutics, thus exerting a synergistic antitumor effect. Phase II/III clinical trials for advanced cancer treatment using a NGR-TNF $\alpha$-based regimen triggered extensive interest in the development of novel TNF $\alpha$-based vessel normalization inducers (Curnis et al. 2004; Fan et al. 2019; Johansson et al. 2012; Yuan et al. 2009). In our previous work, we developed a novel fusion protein Z-TNF $\alpha$ by conjugating a platelet-derived growth factor receptor $\beta$ (PDGFR $\beta$ )specific $Z_{\mathrm{PDGFR} \beta}$ affibody to $\mathrm{TNF} \alpha$. In contrast to NGR$\mathrm{TNF} \alpha$ acting on tumor-associated endothelial cells, Z-TNF $\alpha$ could modulate tumor-associated pericytes, thus inducing vessel normalization, which consequently improved chemotherapy for solid tumors (Fan et al. 2019). The promising vessel normalization mediated by Z-TNF $\alpha$ triggered our interest in comparing Z-TNF $\alpha$ - and NGR-TNF $\alpha$-based combination therapies for solid tumors. As Z-TNF $\alpha$ was produced by using pQE30 in E. coli M15 (Fan et al. 2019), considering the impact of the extra amino acid residuals introduced by the plasmid on the biological activity of TNF $\alpha$, we attempted to prepare recombinant NGR-TNF $\alpha$ via the same expression system.
To construct NGR-TNF $\alpha$, considering NGR (CNGRCG) is a small peptide, we decided to introduce NGR to the Nterminus of mouse TNF $\alpha$ by polymerase chain reaction (PCR) with a specific primer containing an NGR motif. After insertion into pQE30, the amplified gene encoding NGR-TNF $\alpha$ produced a recombinant protein at a high level similar to that of Z-TNF $\alpha$. However, simultaneous sequence verification revealed that a cytosine $(C)$ was changed to guanine $(G)$ in the forward primer, which resulted in a substitution of the leucine (L) by valine (V) at the start of TNF $\alpha$ in NGRTNF $\alpha$. To avoid impact of the amino acid substitution on the biological activity of NGR-TNF $\alpha$, we prepared the gene encoding native NGR-TNF $\alpha$ with leucine at the start of TNF $\alpha$ by chemical synthesis. In brief, the native NGR$\mathrm{TNF} \alpha$ with leucine at the start of TNF $\alpha$ was designated NGR-TNF $\alpha-\mathrm{L}$, while the mutated NGR-TNF $\alpha$ with valine at the start of TNF $\alpha$ was designated NGR-TNF $\alpha-\mathrm{V}$. We were surprised that the expression level of NGR-TNF $\alpha$-L was substantially lower than that of NGR-TNF $\alpha-V$ in the same expression system, suggesting that the single nucleotide mutation altered the gene expression or solubility of the recombinant protein. This unusual phenomenon greatly triggered our interest in investigating the impact of a single nucleotide/ amino acid mutation on the expression and biological activity of NGR-TNF $\alpha$.

In this study, we compared the gene transcription, protein yield, and biological activity of NGR-TNF $\alpha$-L and NGR$\mathrm{TNF} \alpha-\mathrm{V}$. The single nucleotide mutation that caused an amino acid substitution significantly increased the yield but had little impact on the biological activity of NGR-TNF $\alpha$. Moreover, unlike fusion to TNF $\alpha$-L, fusing NGR to TNF $\alpha$ $\mathrm{V}$ did not reduce the yield of fusion proteins. These results suggested that the TNF $\alpha$ gene with a $\mathrm{C}>\mathrm{G}$ mutation could be used to prepare novel tumor-homing TNF $\alpha$ variants that might be expressed at high levels in the E. coli M15-pQE30 system.

\section{Materials and methods}

\section{Protein expression and purification}

The gene encoding NGR-TNF $\alpha-\mathrm{V}$ was amplified by PCR using the forward ( $5^{\prime}$-tcaggatcctgcaacggecgttgcg gcgtcagatcatcttctcaaaattcgagtga- $\left.3^{\prime}\right)$ and reverse (5'tcactggtacctcacagagcaatgactccaaagtagac- $3^{\prime}$ ) primer pairs with the murine TNF $\alpha$ gene in the $\mathrm{pQE} 30$ plasmid as a template (Fan et al. 2019). The primers were synthesized by GenScript (Nanjing, China), and the PCR product was subcloned into the pQE30 plasmid between BamH I and Kpn I according to our previous protocol (Yang et al. 2007). The genes encoding NGR-TNF $\alpha$-L were synthesized and subcloned into the pQE30 plasmid by Convenience Biology Inc. (Changzhou, 
China). Sequence verification was performed by TsingKe Biological Technology Inc. (Chengdu, China). Sequenceverified expression vectors containing the gene encoding NGR-TNF $\alpha-\mathrm{V}$ or NGR-TNF $\alpha$-L were transformed into E. coli M15 and cultured on Luria-Bertani (LB) broth medium plates containing $100 \mu \mathrm{g} / \mathrm{mL}$ ampicillin (Amp) and $30 \mu \mathrm{g} / \mathrm{mL}$ kanamycin (Kan). To induce the expression of recombinant protein, E. coli M15 cells derived from a single colony were inoculated into $3 \mathrm{~mL} \mathrm{LB}$ medium and grown at $37^{\circ} \mathrm{C}$ overnight, followed by transfer and further culture into $1.5 \mathrm{~L}$ fresh LB containing Amp and Kan. When the optical density $\left(\mathrm{A}_{600}\right.$ $\mathrm{nm}$ ) of the cells reached approximately 0.8 , isopropyl-Lthio- $\beta$-D-galactopyranoside (IPTG, $0.05 \mathrm{mM}$ ) was added into the culture, followed by incubation at $26{ }^{\circ} \mathrm{C}$ overnight. The bacteria were collected by centrifugation at $7500 \mathrm{~g}$ at $4{ }^{\circ} \mathrm{C}$ and resuspended into lysis buffer $(50 \mathrm{mM}$ phosphate, $\mathrm{pH} 8.0$, $300 \mathrm{mM} \mathrm{NaCl}$, and $20 \mathrm{mM}$ imidazole). Cells were broken by using a high-pressure homogenizer with 4 processes under 800 bar. The supernatants were collected by centrifugation at $25,000 \mathrm{~g}$ at $4{ }^{\circ} \mathrm{C}$ for $15 \mathrm{~min}$ with 4 repeats. The recombinant proteins with additional $6 \mathrm{His}$-tag were absorbed on Ni-NTA fast flow resin followed by elution with imidazole in phosphate buffer (50 mM phosphate, $\mathrm{pH} 8.0,300 \mathrm{mM} \mathrm{NaCl}$, $300 \mathrm{mM}$ imidazole). NGR-TNF $\alpha$-V proteins recovered from Ni-NTA affinity chromatography were further separated by size exclusion chromatography. The purified proteins were dialyzed against phosphate buffered saline (PBS, $10 \mathrm{mM}$ $\mathrm{Na}_{2} \mathrm{HPO}_{4}, 137 \mathrm{mM} \mathrm{NaCl}, 2.68 \mathrm{mM} \mathrm{KCl}, 2 \mathrm{mM} \mathrm{KH} \mathrm{PO}_{4}$, $\mathrm{pH}$ 7.4) overnight at $4{ }^{\circ} \mathrm{C}$. The protein concentrations were measured using a DC protein assay kit (Bio-Rad, CA). Subsequently, the aliquots were stored at $-80{ }^{\circ} \mathrm{C}$ for further use.

The gene encoding native murine $\mathrm{TNF} \alpha$ with leucine at the start (designated $\mathrm{TNF} \alpha-\mathrm{L}$ in this paper) was cloned into pQE30 in our previous work (Fan et al. 2019). The gene encoding the mutated murine $\mathrm{TNF} \alpha$ with valine at the start (designated $\mathrm{TNF} \alpha-\mathrm{V}$ in this paper) was synthesized by Convenience Biology Inc. (Changzhou, China) and subcloned into $\mathrm{pQE} 30$ at the same site of TNF $\alpha$-L. Both TNF $\alpha$-L and $\mathrm{TNF} \alpha-\mathrm{V}$ were induced under the same conditions for NGR$\mathrm{TNF} \alpha$ variants.

\section{Sodium dodecyl sulfate-polyacrylamide gel electro- phoresis and western blot}

Total proteins from $E$. coli M15 cells or the purified proteins were boiled in sodium dodecyl sulfate-polyacrylamide gel electrophoresis (SDS-PAGE) loading buffer supplemented with or without $\beta$-mercaptoethanol (2-ME) for $10 \mathrm{~min}$ (Fan et al. 2019). After separation, the proteins were visualized by Coomassie brilliant blue R250 staining. To examine recombinant proteins by western blot, the proteins in the gel were transferred to a polyvinylidene fluoride (PVDF) membrane, followed by blocking with $5 \%$ skimmed milk for $1 \mathrm{~h}$ at $37^{\circ} \mathrm{C}$. Subsequently, the PVDF membrane was incubated with antibody against $6 \mathrm{His}$-tag or TNF $\alpha$ (Zsbiology, Beijing, China) in $2.5 \%$ skimmed milk at $37^{\circ} \mathrm{C}$ for $1 \mathrm{~h}$. After three washes with PBS containing $0.05 \%$ Tween 20 for 10 min, the PVDF membrane was incubated with HRP-labeled secondary antibodies (Abcam, Shanghai, China) at $37^{\circ} \mathrm{C}$ for $1 \mathrm{~h}$. Finally, the target proteins were visualized with the enhanced chemiluminescence detection system (GE Healthcare, Uppsala, Sweden).

\section{Quantitative real-time polymerase chain reaction}

To examine gene transcription, an aliquot of the overnight cultured $E$. coli M15 cells was inoculated into $1 \mathrm{~L}$ of fresh LB. When the cells grew to log phase $\left(\mathrm{A}_{600 \mathrm{~nm}} \approx 0.8\right)$, IPTG $(0.05 \mathrm{mM})$ was added into the cells, followed by collection at different time points $(0-21 \mathrm{~h})$. Total RNA was extracted using TRIzol® reagent (Thermo fisher scientific, MA, USA) according to the manufacturer's instructions. RNA concentration was determined using a NanoDrop (Thermo fisher scientific, MA, USA). Reverse transcription of mRNA extracted from $E$. coli M15 cells into cDNA was performed using a high-capacity cDNA synthesis kit (Vazyme, Nanjing, China). Quantitative real-time PCR (qRT-PCR) was performed using the CFX96 Touch Real-Time PCR Detection System (Bio-Rad, CA). The threshold cycles $(\mathrm{Ct})$ were calculated by Bio-Rad CFX Manager. The transcription of recombinant genes was normalized using cysG and hcaT as reference genes (Zhou et al. 2011). To determine the mRNA stability after IPTG induction, the transcription of recombinant genes was arrested by the addition of rifampicin to a final concentration of $500 \mu \mathrm{g} / \mathrm{mL}$ into the cells at steady state of transcription (approximately of $1 \mathrm{~h}$ postinduction). The cells were collected at different time points ( $0-8 \mathrm{~min})$ after addition of rifampicin and immediately frozen in liquid nitrogen (Nouaille et al. 2017). Quantitative assays of the recombinant genes were performed by qRT-PCR. The decrease speed reflected the stability of the recombinant gene. Primers for qRT-PCR of hcaT (forward: 5'-GCTGCTCGGCTTTC TCATCC-3', reverse: 5'-CCAACCACGCAGACCAACC3'), cysG, (forward: 5'-TTGTCGGCGGTGGTGATGTC-3', reverse: 5'-ATGCGGTGAACTGTGGAATAAACG-3'), TNF $\alpha$, (forward: 5'-AGGATCGCATCACCATCACCA-3', reverse: 5'-AGCTGCTCCTCCACTTGGTG), or NGRTNF $\alpha$ (forward: 5'-TCACCATCACGGATCCTGCA-3', reverse: 5'-AGCTGCTCCTCCACTTGGTG-3') were synthesized by Songo Biotech (Shanghai, China).

\section{Size exclusion chromatography}

Size exclusion chromatography (SEC) was performed on an AKTA Pure with a Superdex G-75 XK10/30 column (GE Healthcare, Uppsala, Sweden). Proteins were separated on 
the column at a constant flow rate of $0.5 \mathrm{ml} / \mathrm{min}$, with PBS as the mobile phase and monitoring at $280 \mathrm{nM}$. The apparent molecular weight of proteins was estimated using molecular weight standards, including bovine serum albumin $(\mathrm{Mr}$ 67000), ovalbumin ( $\mathrm{Mr} 43000)$, ribonuclease A ( $\mathrm{Mr} 13700)$, aprotinin (Mr 6512), vitamin B12 (Mr 1355), and cytidine (Mr 234).

\section{Mass spectrometry analysis}

Proteins were denatured in UA buffer ( $8 \mathrm{M}$ urea in $0.1 \mathrm{M}$ Tris$\mathrm{HCl}, \mathrm{pH} 8.5$ ) and were alkylated with $50 \mathrm{mM}$ iodoacetamide (IAA) at room temperature for $1 \mathrm{~h}$ in the dark on a $10 \mathrm{KD}$ centrifugal filter tube, followed by digestion with trypsin (1:50 $(\mathrm{w} / \mathrm{w}))$ in the $\mathrm{ABC}$ solution ( $50 \mathrm{mM}$ ammonium bicarbonate) at $37{ }^{\circ} \mathrm{C}$ overnight. The tryptic peptides were desalted and lyophilized before resuspension in $0.1 \%$ formic acid (FA). A $500 \mathrm{ng}$ of peptides was loaded and separated on a homemade micro-tip C18 column $(75 \mu \mathrm{m} \times 200 \mathrm{~mm}$, packed with ReproSil-Pur C18-AQ, $1.9 \mu \mathrm{m}$ resin, Dr. Maisch Gmbh) over a 40-min gradient (buffer A, 0.1\% FA; buffer B, $0.1 \%$ FA in ACN) on a nanoflow HPLC Easy-nLC 1200 system coupled to Orbitrap Fusion Lumos (Thermo Fisher Scientific, MA). The MS1 full scan was acquired at a resolution of 60,000, a scan range of 350-2000 m/z, AGC target 1e6, and maximum injection time of $50 \mathrm{~ms}$. Precursor ions with charge from $2+$ to $8+$ were selected at a $1.6 \mathrm{~m} / \mathrm{z}$ isolation window for $\mathrm{MS} / \mathrm{MS}$ scans with a resolution of 30,000 , AGC target $4 \mathrm{e} 4$, and maximum injection time of $54 \mathrm{~ms}$, following stepped-HCD fragmentation. The raw data were analyzed by BioPharma Finder 4.0. The digestion of enzyme was set as trypsin, and two missed cleavage sites were allowed. The carbamidomethyl cysteine, disulfide bond, methionine oxidation, asparagine, and glutamine (NQ) deamidation were set as variable modifications. Mass error tolerance was set to $5 \mathrm{ppm}$. The peptidespectrum matches (PSMs) of deamidated peptides were examined manually.

\section{Cell culture and cytotoxicity assay}

Murine fibroblasts (L929) purchased from American Type Culture Collection (ATCC) were cultured in Dulbecco'smodified Eagle's medium (DMEM) supplemented with $10 \%$ fetal bovine serum, $2 \mathrm{mM} \mathrm{L}$-glutamine, $100 \mathrm{U} / \mathrm{mL}$ penicillin, and $100 \mu \mathrm{g} / \mathrm{mL}$ streptomycin at $37{ }^{\circ} \mathrm{C}$ in a $5 \% \mathrm{CO}_{2}$ humidified atmosphere. To measure the cytotoxicity of proteins, L929 cells were inoculated into 96-well plates at $1 \times 10^{4}$ per well. After overnight culture, L929 cells were pretreated with $100 \mu \mathrm{L}$ actinomycin-D (ACTD, $4 \mu \mathrm{g} / \mathrm{mL}$ ) for $30 \mathrm{~min}$ prior to the addition of different concentrations of protein (Hoffmann et al. 2010). Surviving cells were measured using a cell counting kit-8 (CCK-8, Dojindo, Japan) 16 h later. PBS was used as a control. The viability of cells treated with protein was expressed as a percentage of PBS-treated cells. The live/ dead backlight bacterial viability kit (Molecular robes, CA) was used to visualize dead and live cells. After treatment with proteins, cells were dually stained with the membranepermeable SYTO $9(15 \mu \mathrm{M})$ and the membraneimpermeable propidium iodide (PI, $2.5 \mu \mathrm{g} / \mathrm{mL}$ ), followed by observation under a fluorescence microscope. The live and dead cells were illustrated as green and red, respectively.

\section{Receptor binding assays}

Biolayer interferometry was performed on the 2-Channel Entry-Level Octet System Octet K2 (Pall ForteBio LLC, CA). To examine the binding of TNF $\alpha$ proteins to TNF receptors, TNFR1-Fc or TNFR2-Fc (Sino Biological, Beijing, China) was first immobilized onto a protein A-coated biosensor. Subsequently, the biosensor was inserted into 50,100 , or $250 \mathrm{nM}$ TNF $\alpha$ proteins dissolved in HBS-EP buffer $(10 \mathrm{mM}$ HEPES, pH 7.4, $150 \mathrm{mM} \mathrm{NaCl}, 3 \mathrm{mM}$ EDTA, and $0.005 \%$ Tween 20) for association and dissociation. The kinetic constants, including the association constant $(\mathrm{ka})$ and dissociation constant $(\mathrm{kd})$ and affinity $(\mathrm{KD}, \mathrm{KD}=\mathrm{kd} / \mathrm{ka})$, were calculated using data analysis software according to a 1:1 binding model. The CD13 expression in HT1080 cells was measured by flow cytometry (Kessler et al. 2018). To verify the interaction between NGR domain in fusion protein and CD13 on the cell surface, HT1080 cells were incubated with different concentration (100-500 nM) of FAM-labeled TNF $\alpha$ proteins at room temperature for $1 \mathrm{~h}$ prior to flow cytometry analysis. FAM labeling of protein was performed according to our previous work (Fan et al. 2019).

\section{Tumor-bearing mice and treatment}

Tumor-bearing mice were constructed by subcutaneous inoculation of $1 \times 10^{5} \mathrm{~B} 16 \mathrm{~F} 1$ cells into $\mathrm{C} 57 \mathrm{BL} / 6$ female mice $(6$ weeks old). Mice were randomly divided into 6 groups $(n=7)$ on day 7 postinoculation, followed by treatment with TNF $\alpha$ proteins combined with or without doxorubicin (DOX). $\mathrm{TNF} \alpha$ protein $(1 \mu \mathrm{g} / \mathrm{mouse})$ and DOX $(3 \mathrm{mg} / \mathrm{kg})$ were intravenously injected into tumor-bearing mice every other day for a total of five times. The mice in the control group were administered the same volume of PBS. Tumor grafts were measured every day, and the tumor volume was calculated by the formula: tumor volume $=$ length $\times$ width $^{2} \times 0.5$. The survival rates and body weights of mice were recorded every day.

\section{Statistical analysis}

The results are presented as the means \pm standard deviation (SD) from at least three independent experiments. One-way analysis of variance (ANOVA) for multiple comparisons was performed to analyze the differences among groups using 
SPSS software version 13.0. The significance level was defined as $p<0.05$.

\section{Results}

\section{A single nucleotide mutation drastically increases the yield of NGR-TNFa in the E. coli M15-pQE30 expres- sion system}

As shown in Fig. 1a, the gene encoding NGR-TNF $\alpha$-L differs from the gene encoding NGR-TNF $\alpha-\mathrm{V}$ at a single nucleotide $(\mathrm{C}>\mathrm{G})$ within the initial codon of TNF $\alpha$, which causes the substitution of leucine (L) at the start of TNF $\alpha$ by valine (V). To compare their difference in expression level, pQE30 plasmids containing the gene encoding NGR-TNF $\alpha$-L (pQE30NGR-TNF $\alpha-\mathrm{L})$ or NGR-TNF $\alpha-\mathrm{V}$ (pQE30-NGR-TNF $\alpha-\mathrm{V})$ were transformed into $E$. coli M15 cells. Owing to the known similarity between colonies of $E$. coli M15, we randomly collected $E$. coli M15 cells containing an expression vector from a single colony for further protein expression analysis. As shown in Fig. 1b, SDS-PAGE of total proteins from bacteria indicated clear accumulation of a protein band with an apparent molecular weight of $18 \mathrm{KD}$ in $E$. coli M15 cells containing pQE30-NGR-TNF $\alpha-V$ after induction with IPTG overnight. These induced proteins accounted for approximately $20 \%$ of total bacterial proteins predominantly existing as soluble proteins, but not insoluble inclusion bodies, in E. coli M15 cells.
Further western blot with antibody against 6 His-tag verified these induced proteins as NGR-TNF $\alpha-\mathrm{V}$, indicating that the gene encoding NGR-TNF $\alpha-\mathrm{V}$ was highly expressed in the E. coli M15-pQE30 system. However, according to the total protein analysis and western blot, little accumulation of NGRTNF $\alpha$-L was observed in E. coli M15 cells containing pQE30-NGR-TNF $\alpha$-L after induction under the same conditions (Fig. 1c), demonstrating that the efficacy of NGR$\mathrm{TNF} \alpha-\mathrm{L}$ in inductive expression was much lower than that of NGR-TNF $\alpha-V$ in the same E. coli M15-pQE30 expression system. To validate this, inductive expression of the genes encoding NGR-TNF $\alpha-\mathrm{V}$ and NGR-TNF $\alpha$-L was further compared in E. coli M15 derived from three individual colonies. As shown in Fig. 2a and b, E. coli M15 cells derived from three individual colonies containing pQE30-NGR$\mathrm{TNF} \alpha-\mathrm{V}$ produced NGR-TNF $\alpha-\mathrm{V}$ as soluble proteins at a similarly high level. However, E. coli M15 cells derived from three individual colonies containing pQE30-NGR-TNF $\alpha$-L only expressed a small amount of NGR-TNF $\alpha-\mathrm{L}$ under the same conditions. Both NGR-TNF $\alpha-\mathrm{V}$ and NGR-TNF $\alpha$-L could be purified to homogeneity by Ni-NTA affinity chromatography (Fig. 2c and d). Further quantitative assays for the purified proteins demonstrated that the average yield of NGR$\mathrm{TNF} \alpha-\mathrm{V}$ was over $20 \mathrm{mg} / \mathrm{L}$, compared to $0.2 \mathrm{mg} / \mathrm{L}$ for that of NGR-TNF $\alpha$-L, demonstrating that the yield of NGR-TNF $\alpha$ $\mathrm{V}$ was approximately 100 times higher than that of NGRTNF $\alpha$-L in the $E$. coli M15-pQE30 system. These results indicated that the single $\mathrm{C}>\mathrm{G}$ mutation in the gene encoding NGR-TNF $\alpha$ drastically increased the expression of NGR$\mathrm{TNF} \alpha$ protein.

\section{$\mathrm{N}$-terminus of NGR-TNFa variants}

NGR-TNFa-L: 5'-atgagaggatcgcatcaccatcaccatcacggatcc tgcaacggccgttgcggcctcagatcatcttctcaaaat-3'

NGR-TNFa-V: 5'-atgagaggatcgcatcaccatcaccatcacggatcc tgcaacggccgttgcggcgtcagatcatcttctcaaaat-3'

NGR-TNFa-L: NH$_{2}$-MRGSHHHHHHGSCNGRCGLRSSSQN-COOH NGR-TNFa-V: $\mathrm{NH}_{2}$-MRGSHHHHHHGSCNGRCGVRSSSQN-COOH
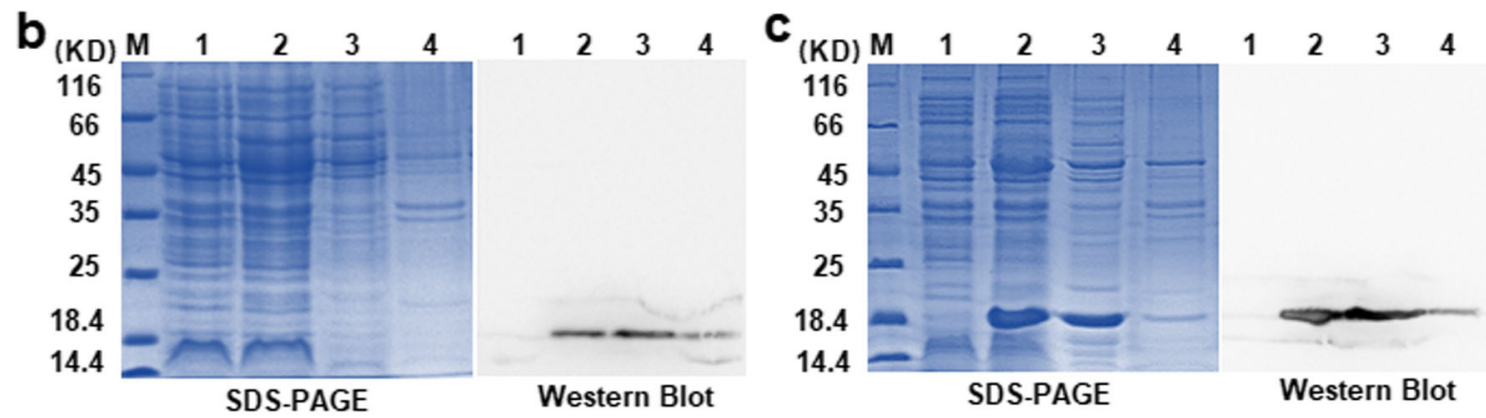

$\mathrm{TNF} \alpha-\mathrm{V})(\mathbf{b})$ and native NGR-TNF $\alpha(\mathrm{NGR}-\mathrm{TNF} \alpha-\mathrm{L})(\mathbf{c})$ in the presence of 2-ME. M, protein markers; lane 1, the total proteins of uninduced cells; lane 2 , the total proteins of induced cells; lane 3 , the soluble proteins of induced cells; lane 4, the insoluble proteins of induced cells 
a
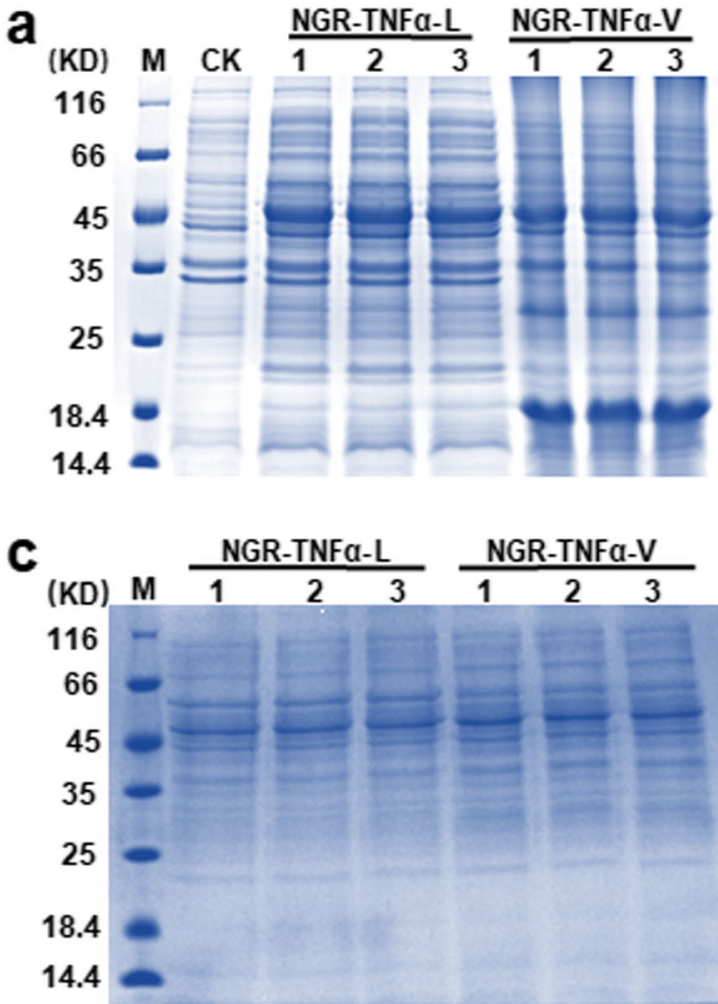

b

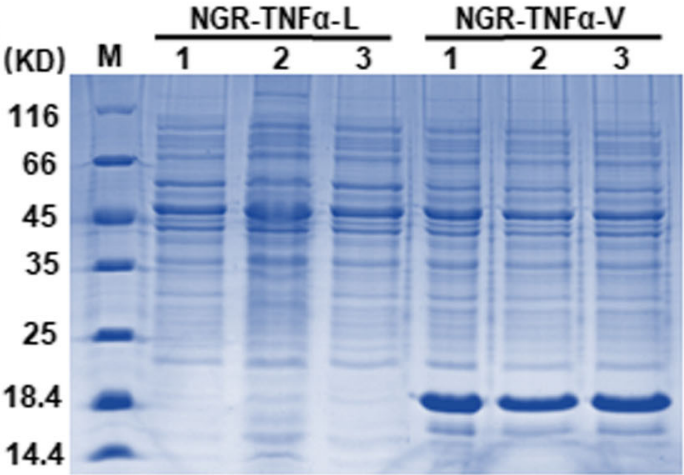

d

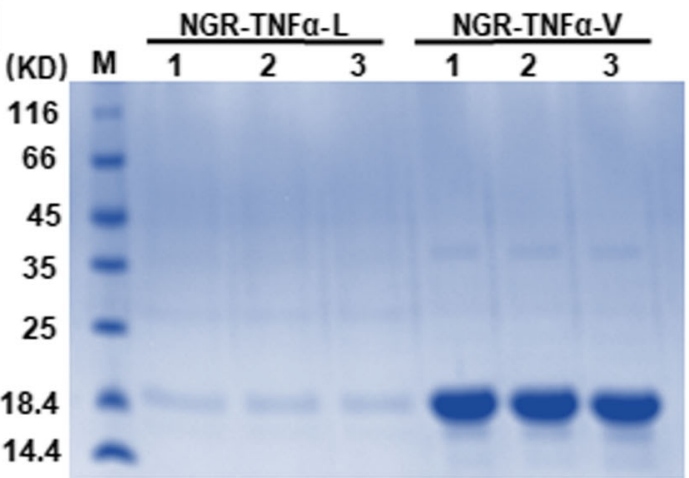

e

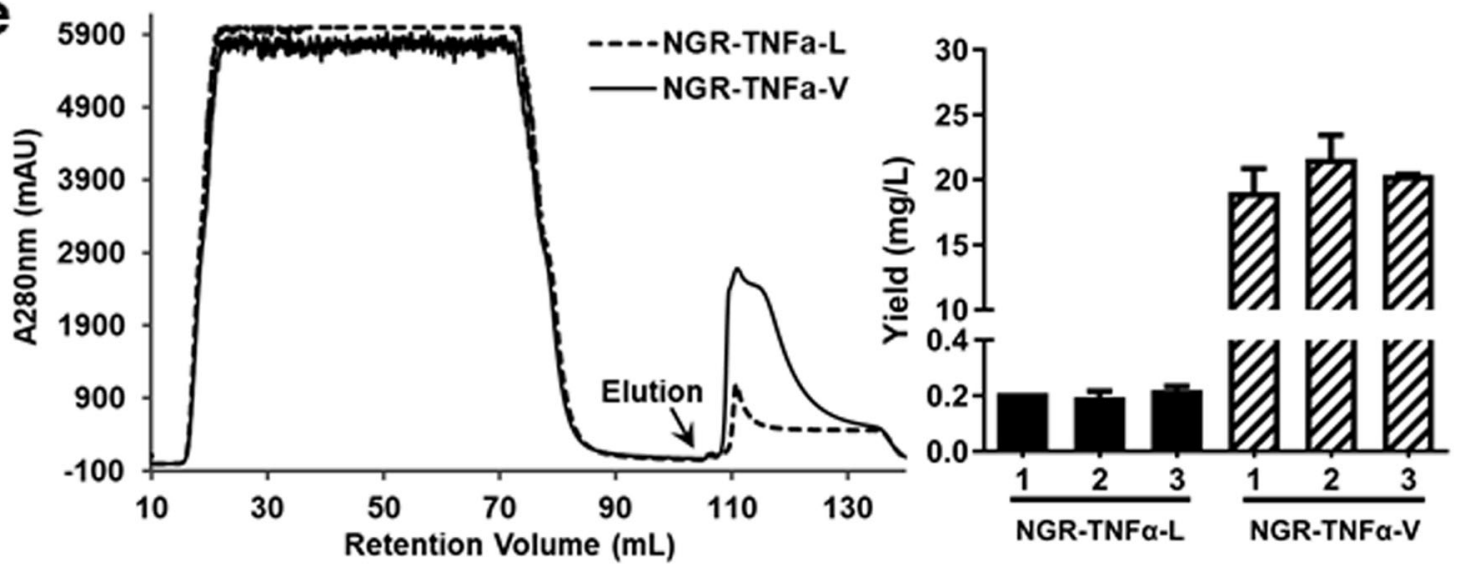

Fig. 2 Purification of soluble proteins from E. coli M15 cells with the pQE30-NGR-TNF $\alpha$ plasmid. a Total proteins of E. coli M15 cells induced by IPTG. b Soluble proteins of $E$. coli M15 cells after disruption by a high-pressure homogenizer. c Flow through of soluble proteins after adsorption by Ni-NTA super flow. d NGR-TNF $\alpha$ proteins purified by
Ni-NTA affinity chromatography. e Chromatogram of soluble proteins from induced $E$. coli M15 cells and the yield of purified NGR-TNF $\alpha$ proteins. CK: E. coli M15 cells. 1, 2, 3: three individual colonies of E. coli $\mathrm{M} 15$ cells containing the $\mathrm{pQE} 30-\mathrm{NGR}-\mathrm{TNF} \alpha$ plasmid
As this single nucleotide mutation $(\mathrm{C}>\mathrm{G})$ occurred in the initial codon of TNF $\alpha$, we further investigated the impact of this mutation on the inductive expression of TNF $\alpha$. As shown in Fig. 3a, the gene encoding native TNF $\alpha$ with leucine at the start $(\mathrm{TNF} \alpha-\mathrm{L})$ differs from that encoding mutated $\mathrm{TNF} \alpha$ with valine at the start $(\mathrm{TNF} \alpha-\mathrm{V})$ at a single nucleotide. These genes inserted into $\mathrm{pQE30}$ were inductively expressed by IPTG in E. coli M15 (Fig. 3b). Similar to NGR-TNF $\alpha$ variants, both $\mathrm{TNF} \alpha-\mathrm{V}$ and
$\mathrm{TNF} \alpha$-L were predominantly expressed as soluble proteins, which was easily purified to homogeneity by simple Ni-NTA affinity chromatography (Fig. 3c, d, and e). According to the quantitative assay for the purified soluble proteins, the yield of TNF $\alpha-\mathrm{V}$ was approximately $2-3$-fold $(14.1 \pm 2.3 \mathrm{mg} / \mathrm{L}$ vs $6.1 \pm 2.1 \mathrm{mg} / \mathrm{L})$ that of TNF $\alpha-\mathrm{L}$ (Fig. $3 \mathrm{f}$ ), indicating that the single nucleotide mutation improved the expression of TNF $\alpha$ in the E. coli M15pQE30 system. 
Fig. 3 Purification of proteins from $E$. coli $\mathrm{M} 15$ cells containing the $\mathrm{pQE} 30-\mathrm{TNF} \alpha$ plasmid. a Schematic diagram of the $\mathrm{PQE} 30$ $\mathrm{TNF} \alpha$ plasmid and the single nucleotide mutation of $\mathrm{C}$ to $\mathrm{G}$ in the initial codon of $\mathrm{TNF} \alpha$ resulting in a leucine (L) substitution with valine $(\mathrm{V})$. b Total proteins of E. coli $\mathrm{M} 15$ cells induced by IPTG. c Soluble proteins. d Flow through of soluble proteins after adsorption by Ni-NTA super flow. $\mathrm{e} T \mathrm{TF} \alpha$ proteins purified by Ni-NTA affinity chromatography. f Chromatogram of soluble proteins from induced $E$. coli $\mathrm{M} 15$ cells and the yield of purified $\mathrm{TNF} \alpha$ proteins. CK: E. coli M15 cells. 1, 2, 3: three individual colonies of $E$. coli $\mathrm{M} 15$ cells containing the $\mathrm{pQE} 30-\mathrm{TNF} \alpha$ plasmid a

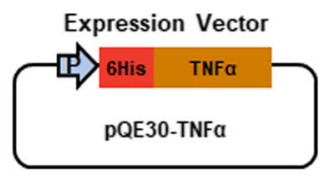

b

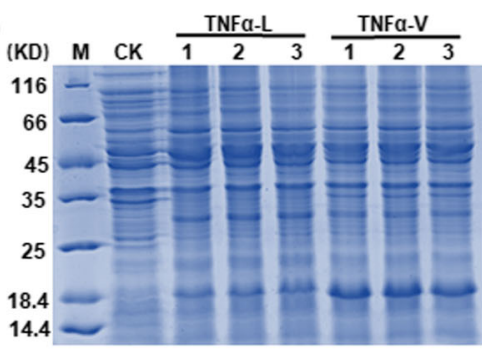

d

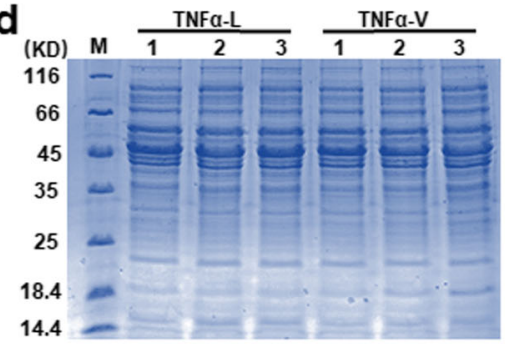

$\mathrm{N}$-terminus of TNFa variants

TNFa-L: 5'-atgagaggatcgcatcaccatcaccatcacggatcc ctcagatcatcttctcaaaat-3'

TNFa-V: 5'- atgagaggatcgcatcaccatcaccatcacggatcc gtcagatcatcttctcaaaat-3'

TNFa-L: $\mathrm{NH}_{2}$-MRGSHHHHHHGSLRSSSQN-COOH TNFa-V: $\mathrm{NH}_{2}$-MRGSHHнHHHGSVRSSSQN-COOH

C

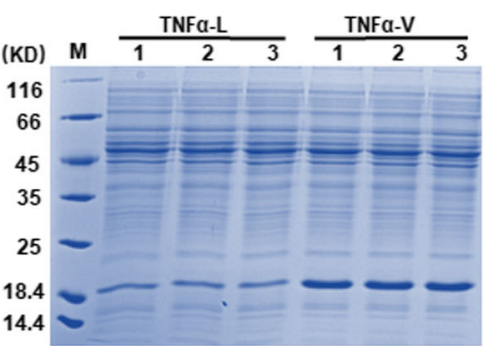

e

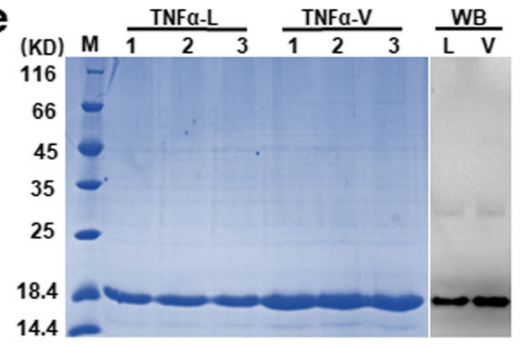

f
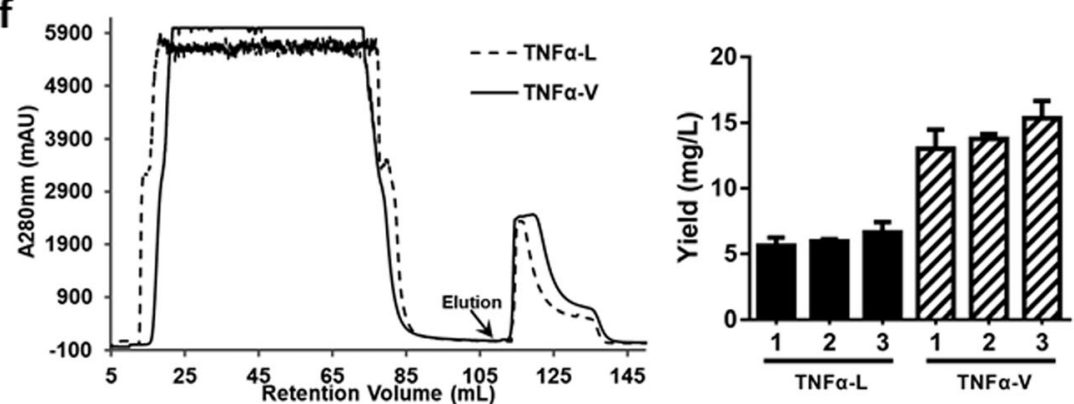

\section{A single nucleotide mutation enhances the gene transcription of NGR-TNFa in the $E$. coli M15-pQE30 expression system}

As nucleotide mutations might change gene expression by altering the transcriptional efficacy and stability of mRNA, the accumulation of transcripts for all TNF $\alpha$ variants in E. coli M15 cells was first analyzed by qRT-PCR. After induction by IPTG for different times, the E. coli M15 cells containing $\mathrm{pQE} 30$ expression vectors for $\mathrm{TNF} \alpha$ variants were collected, followed by total RNA extraction for qRT-PCR. The expression level of TNF $\alpha$ variants in E. coli M15 cells collected at different times postinduction was normalized to that in cells collected at $0 \mathrm{~h}$ (before addition of IPTG), calculated as 1. As shown in Fig. 4a, the mRNA transcription level of NGR-TNF $\alpha-\mathrm{V}$ increased 400-600 times after induction for $0.5-1 \mathrm{~h}$ and persisted at a high level (approximately 400-fold that at $0 \mathrm{~h}$ ) to at least $21 \mathrm{~h}$ postinduction. However, NGR$\mathrm{TNF} \alpha-\mathrm{L}$ transcripts did not clearly increase with time after induction by addition of IPTG. Similar to that of NGR$\mathrm{TNF} \alpha-\mathrm{V}$, accumulation of TNF $\alpha-\mathrm{V}$ transcripts increased with time and peaked (120-fold that at $0 \mathrm{~h}$ ) at $2 \mathrm{~h}$ postinduction, followed by a decrease to basic level at $21 \mathrm{~h}$ postinduction. After induction, accumulation of $\mathrm{TNF} \alpha-\mathrm{L}$ transcripts increased with time and peaked (80-fold that at $0 \mathrm{~h}$ ) at $1 \mathrm{~h}$ postinduction, followed by a decrease to basic levels within $4 \mathrm{~h}$ (Fig. 4b). These results demonstrated that a single nucleotide mutation $(\mathrm{C}>\mathrm{G})$ significantly increased the transcriptional efficacy of NGR-TNF $\alpha$ in the $E$. coli M15-pQE30 expression system. mRNA stability is another impact factor for protein yield. Usually, mRNAs encoding most proteins are stable for a short time in $E$. coli, with a half-life less than $5 \mathrm{~min}$ (Esquerre et al. 2014). To assess mRNA stability, transcription machinery was blocked by the addition of rifampicin into $E$. coli once the transcription was at a steady state (approximately $1 \mathrm{~h}$ postinduction). As shown in Fig. 4c and d, no obvious difference was observed in the mRNA decrease after the addition of rifampicin between genes encoding all four 

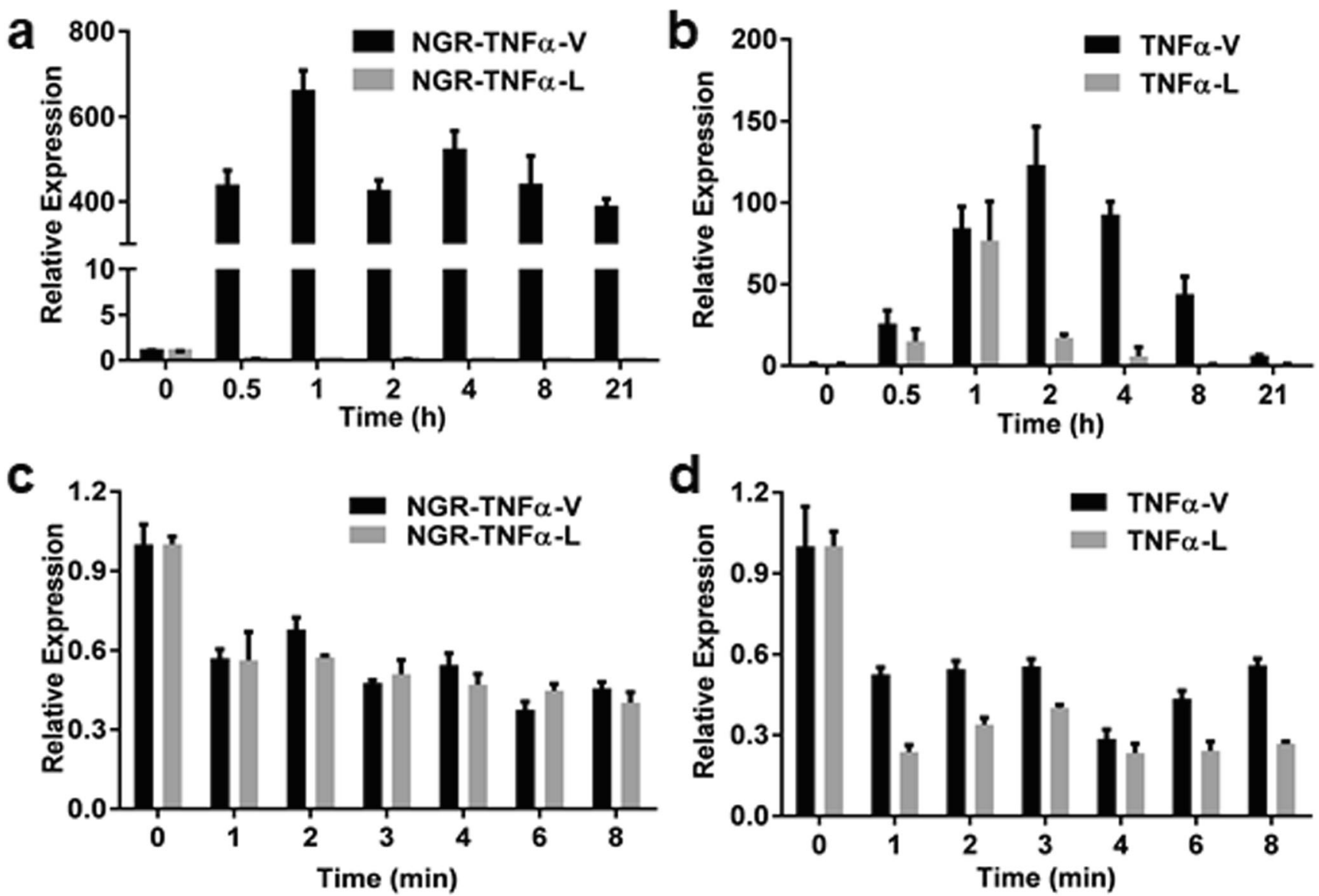

Fig. 4 Time-dependent transcription of TNF $\alpha$ proteins. a,b To determine the transcription efficiency, mRNA of NGR-TNF $\alpha$ (a) and TNF $\alpha(\mathbf{b})$ variants was measured by qRT-PCR at different times postinduction with IPTG. c,d To determine the stability of mRNA, transcription was

$\mathrm{TNF} \alpha$ variants, indicating that the single nucleotide mutation $(\mathrm{C}>\mathrm{G})$ did not reduce the stability of genes encoding TNF $\alpha$ variants. Accordingly, the accumulation of these TNF $\alpha$ proteins in E. coli M15 cells was consistent with their gene expression profile. As shown in Fig. S1, NGR-TNF $\alpha-\mathrm{V}$ was clearly produced at $0.5 \mathrm{~h}$ and accumulated more within $21 \mathrm{~h}$ postinduction. However, little NGR-TNF $\alpha$-L accumulation was observed throughout the time-course analysis. The expression level of TNF $\alpha$-L was also lower than that of $\mathrm{TNF} \alpha-\mathrm{V}$. These results demonstrated that the single nucleotide mutation $(\mathrm{C}<\mathrm{G})$ increased the yields of the NGR-TNF $\alpha$ and $\mathrm{TNF} \alpha$ predominantly by improving gene transcription.

\section{A single nucleotide mutation-induced amino acid substitution does not reduce the receptor binding of NGR-TNFa}

The NGR-TNF $\alpha-V$ purified by Ni-NTA affinity chromatography combined with SEC was visualized as a single protein band corresponding to its monomers on SDS-PAGE gel in the presence (Fig. 2d) or in the absence (Fig. 5a) of 2-ME. terminated by addition of rifampicin into the culture. Subsequently, the mRNA levels of NGR-TNF $\alpha(\mathbf{c})$ and TNF $\alpha(\mathbf{d})$ variants were measured by qRT-PCR at different time points after addition of rifampicin

Accordingly, NGR-TNF $\alpha-\mathrm{V}$ exhibits a single peak on the SEC column (Fig. 5b). Further mass spectrometry verified the purified protein as NGR-TNF $\alpha-\mathrm{V}$ according to the Nterminal amino acid sequence (Fig. 5c). In contrast, NGR$\mathrm{TNF} \alpha$-L was visualized as a single protein band on the gel of SDS-PAGE in the presence of 2-ME (Fig. 3e). In the absence of 2-ME, NGR-TNF $\alpha$-L was illustrated as at least two protein bands corresponding to its monomer and dimer (Fig. 5a). Moreover, NGR-TNF $\alpha$-L exhibited three protein peaks on the SEC column under naturing conditions (Fig. 5b). However, both $\mathrm{TNF} \alpha-\mathrm{L}$ and $\mathrm{TNF} \alpha-\mathrm{V}$ were showed as single protein peaks on the SEC column (Fig. S2a), suggesting that oligomerization of NGR-TNF $\alpha-\mathrm{L}$ was induced by the fused NGR with cysteine residues that could form unexpected intermolecular disulfide bond. Notably, according to the SEC of proteins recovered by a single step of Ni-NTA affinity chromatography, the single nucleotide mutation-induced amino acid change from $\mathrm{L}$ to $\mathrm{V}$ in $\mathrm{TNF} \alpha$ decreased the aggregation of NGRTNF $\alpha$ (Fig. S2b).

NGR-TNF $\alpha$ can bind TNFR and CD13. Biolayer interferometry was used to evaluate the impact of the single amino 
a

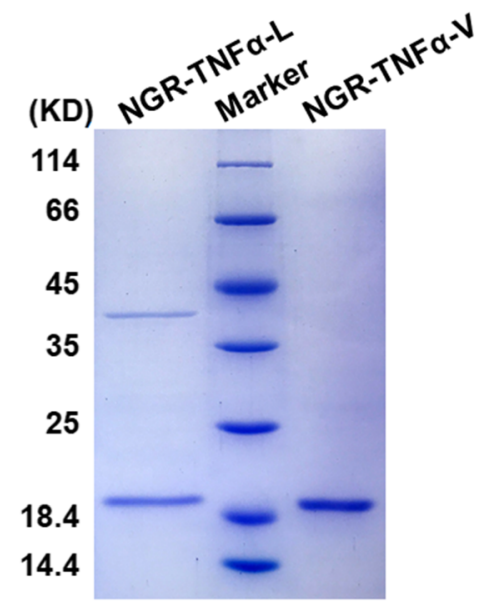

b

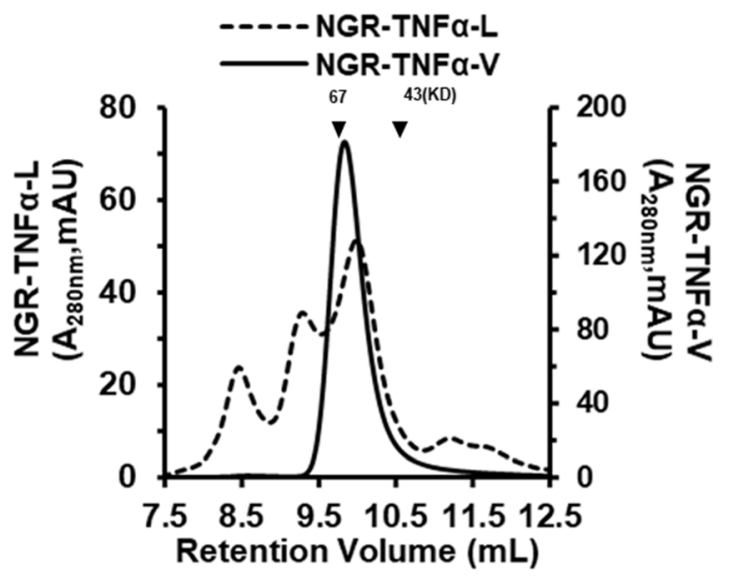

C

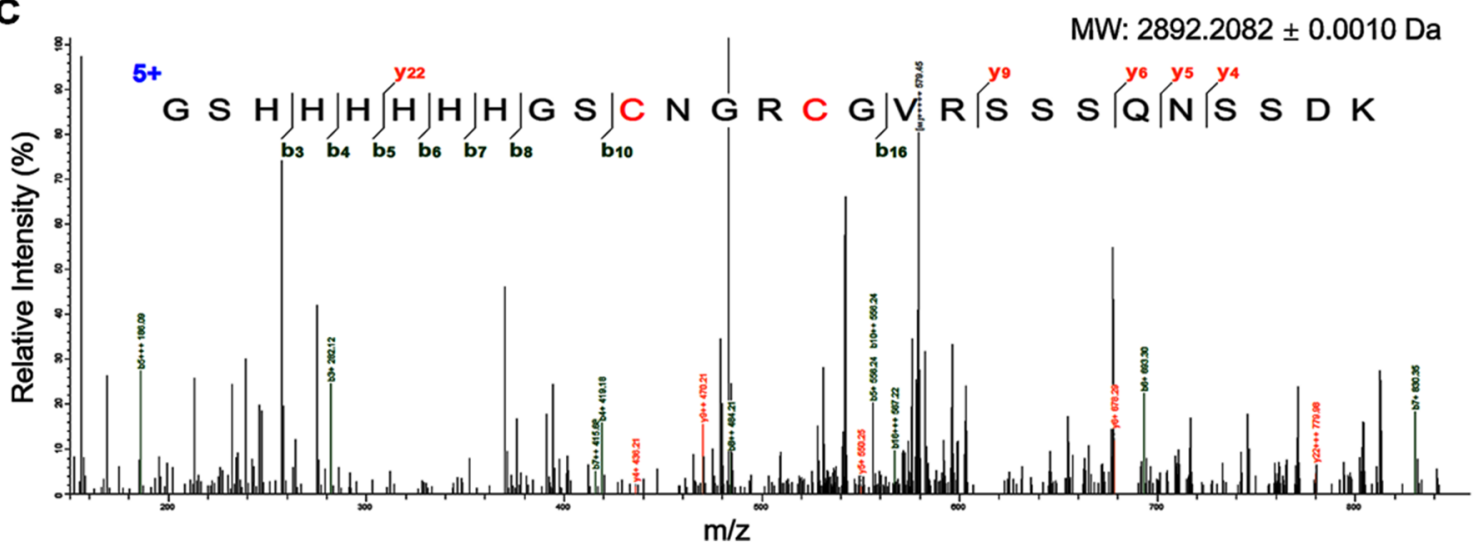

Fig. 5 Polymerization analysis of NGR-TNF $\alpha$ variants. a Size exclusion chromatography of NGR-TNF $\alpha-\mathrm{V}$ and NGR-TNF $\alpha$-L was performed on Superdex G-75 XK10/30. The molecular weights of these proteins were calibrated with protein markers. b SDS-PAGE of NGR-TNF $\alpha-\mathrm{V}$ and
NGR-TNF $\alpha$-L in the absence of 2-ME. To determine the stability of $\mathrm{TNF} \alpha$ proteins, the cytotoxicity of these proteins was measured using L929 cells after the proteins were stored at $37^{\circ} \mathrm{C}$ for different times acid mutation on the receptor binding of NGR-TNF $\alpha$. As shown in Table 1 and Fig. S3a, the affinity of TNF $\alpha-\mathrm{V}$ for TNFR $(0.3 \pm 0.1 \mathrm{nM}$ for TNFR1, $1.9 \pm 0.1 \mathrm{nM}$ for TNFR2 $)$ was similar to that of TNF $\alpha$-L for TNFR $(0.3 \pm 0.1 \mathrm{nM}$ for TNFR1, $2.1 \pm 0.1 \mathrm{nM}$ for TNFR2), indicating that the single

Table 1 Affinity of TNF $\alpha$ proteins for TNF $\alpha$ receptors

\begin{tabular}{llllll}
\hline & \multicolumn{2}{l}{ TNFR1 } & & \multicolumn{2}{l}{ TNFR1 } \\
\cline { 2 - 3 } \cline { 5 - 6 } Protein & KD(M) & KD Error & & KD(M) & \multicolumn{2}{l}{ KD Error } \\
\hline TNF $\alpha-\mathrm{L}$ & $3.088 \mathrm{E}-10$ & $4.604 \mathrm{E}-11$ & & $2.103 \mathrm{E}-09$ & $1.028 \mathrm{E}-10$ \\
$\mathrm{TNF} \alpha-\mathrm{V}$ & $3.258 \mathrm{E}-10$ & $6.846 \mathrm{E}-11$ & & $1.862 \mathrm{E}-09$ & $1.411 \mathrm{E}-10$ \\
NGR-TNF $\alpha-\mathrm{L}$ & $7.409 \mathrm{E}-10$ & $2.302 \mathrm{E}-10$ & & $4.634 \mathrm{E}-09$ & $2.933 \mathrm{E}-10$ \\
NGR-TNF $\alpha-\mathrm{V}$ & $5.261 \mathrm{E}-10$ & $8.743 \mathrm{E}-11$ & & $2.452 \mathrm{E}-09$ & $1.941 \mathrm{E}-10$ \\
\hline
\end{tabular}

amino acid mutation did not change the TNFR binding of TNF $\alpha$. NGR-TNF $\alpha-V$ and NGR-TNF $\alpha$-L showed comparable affinity for TNFR1 $(0.5 \pm 0.1 \mathrm{nM}$ vs $0.7 \pm 0.2 \mathrm{nM})$. Nevertheless, the affinity of NGR-TNF $\alpha$-V for TNFR2 (2.5 $\pm 0.2 \mathrm{nM})$ was slightly higher than that $(4.6 \pm 0.3 \mathrm{nM})$ of NGR-TNF $\alpha$-L for TNFR2 (Table 1 and Fig. S3b). The binding of TNF $\alpha$ proteins to CD13 was measured by cell binding analysis. As shown in Fig. 6a, CD13 was overexpressed in HT1080 cells. Both NGR-TNF $\alpha-V$ and NGR-TNF $\alpha$-L exhibited a similar binding to HT1080 cells (Fig. 6b). However, TNF $\alpha$-V and TNF $\alpha$-L showed no obvious binding to HT1080 cells (Fig. 6c), indicating that the NGR motif in the fusion proteins preserved CD13-binding ability. These results demonstrated that the single nucleotide mutation-induced amino acid substitution had a little impact on the receptor binding of NGR-TNF $\alpha$. 


\section{A single nucleotide mutation-induced amino acid substitution does not alter the in vitro cytotoxicity or in vivo synergistic antitumor effect of NGR-TNFa}

Figure $7 \mathrm{a}$ and $\mathrm{b}$ showed that all the TNF $\alpha$ proteins exhibited weak cytotoxicity in L929 cells pretreated without ACTD. Quantitative assays demonstrated that these proteins only induced $20-40 \%$ cell death at high concentrations (10-100 ng/ $\mathrm{mL})$. However, these proteins induced over $90 \%$ cell death a low concentration of $0.5 \mathrm{ng} / \mathrm{mL}$ in L929 cells pretreated with ACTD. In particular, the cytotoxicity of NGR-TNF $\alpha-V$ was comparable to that of NGR-TNF $\alpha$-L in L929 cells pretreated with ACTD. In addition, $\mathrm{TNF} \alpha-\mathrm{V}$ was also similar to TNF $\alpha$ $\mathrm{L}$ in in vitro cell killing. Further live/dead cell visualization using SYTO9/PI dual staining verified the cytotoxicity of these TNF $\alpha$ proteins, demonstrating that the single amino acid substitution of $\mathrm{L}$ by $\mathrm{V}$ at the start of TNF $\alpha$ did not reduce the in vitro cytotoxicity of the native TNF $\alpha$ proteins. Stability assays demonstrated that all TNF $\alpha$ proteins displayed comparable activity without evident decline within 5 days (Fig. 7c), demonstrating that changing the amino acid from $\mathrm{L}$ to $\mathrm{V}$ at the start of TNF $\alpha$ had little impact on the stability of NGR-TNF $\alpha$.
Fig. 6 Binding of TNF $\alpha$ proteins to CD13-expressing HT1080 cells. a Expression of CD13 in HT1080 cells indicated by flow cytometry with an antibody against CD13 ( $\alpha$-CD13). b,c Binding of TNF $\alpha$ proteins to HT1080 cells. FAM-labeled $\mathrm{TNF} \alpha$ proteins $(100-500 \mathrm{nM})$ were incubated with HT1080 cells for $1 \mathrm{~h}$ at room temperature prior to flow cytometry analysis

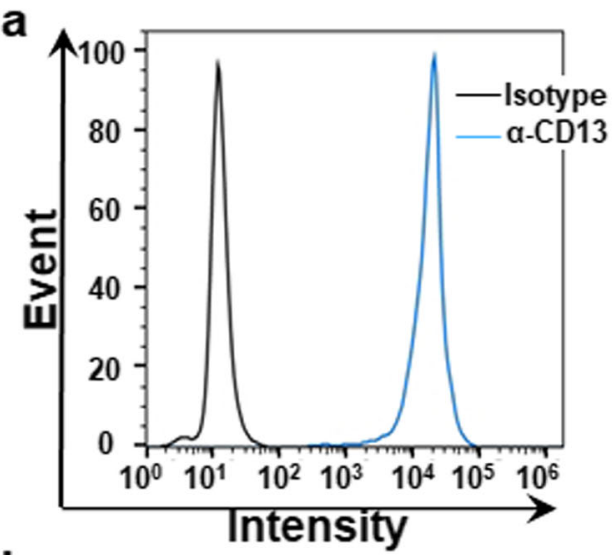

b

NGR-TNFa-L
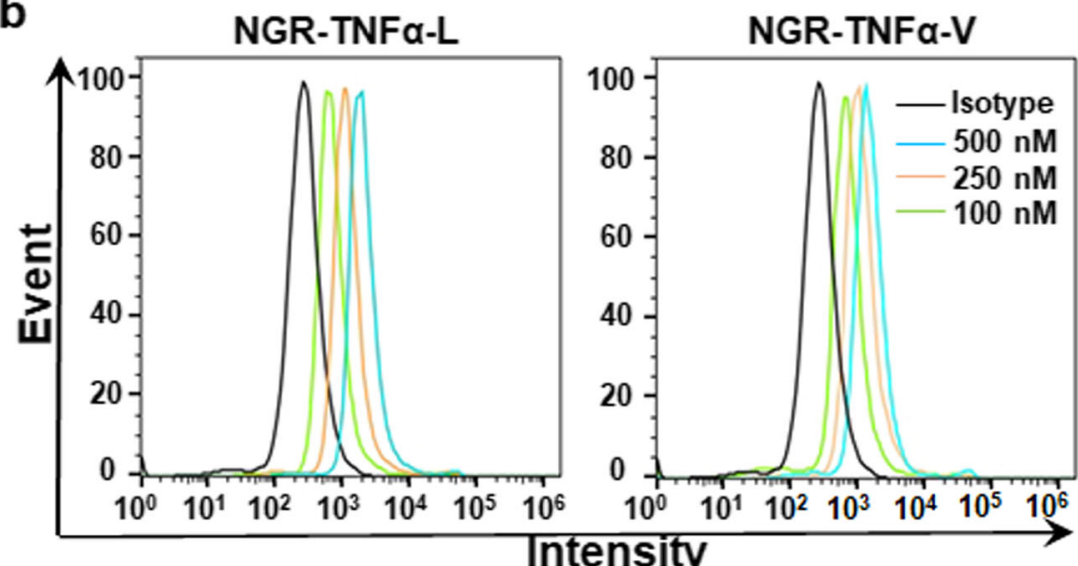

C

TNFa-L

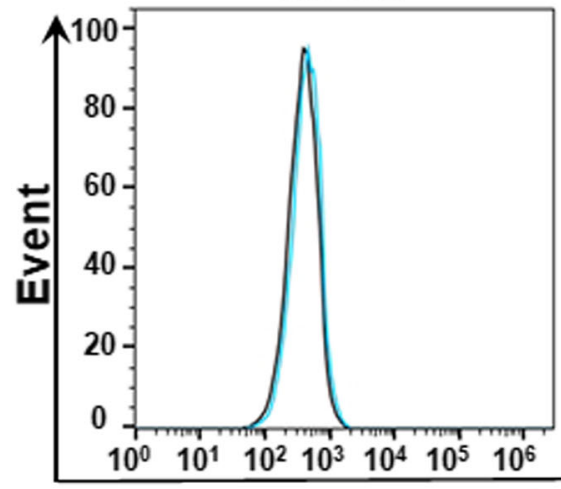

TNFa-V

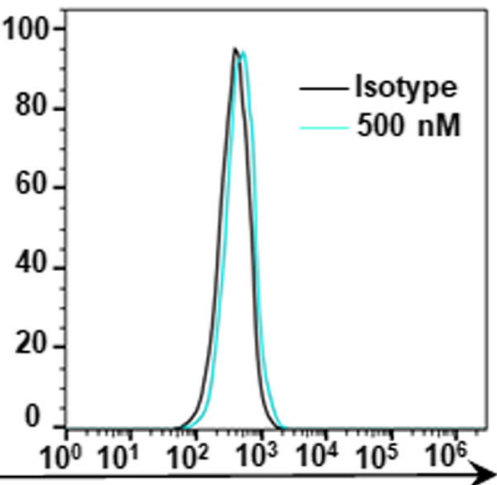

\section{Intensity}


a

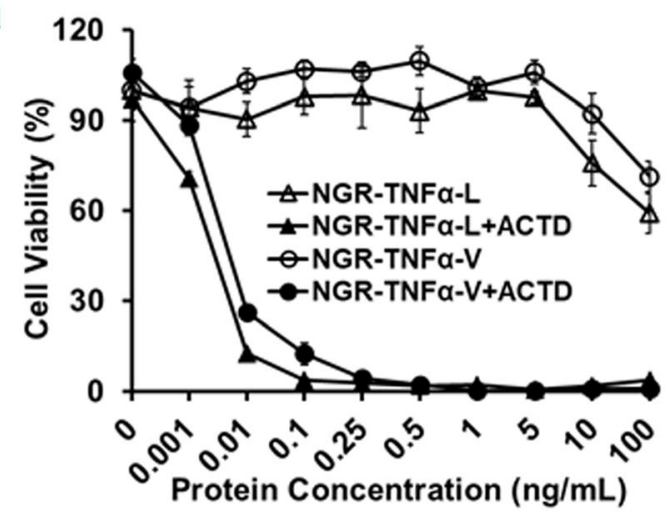

b

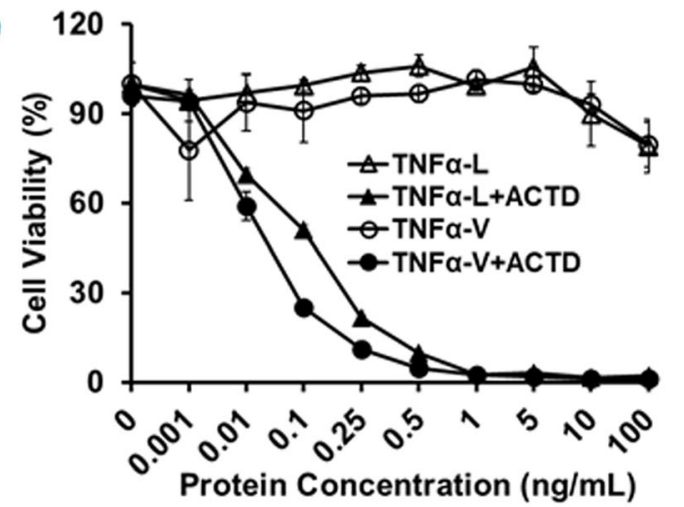

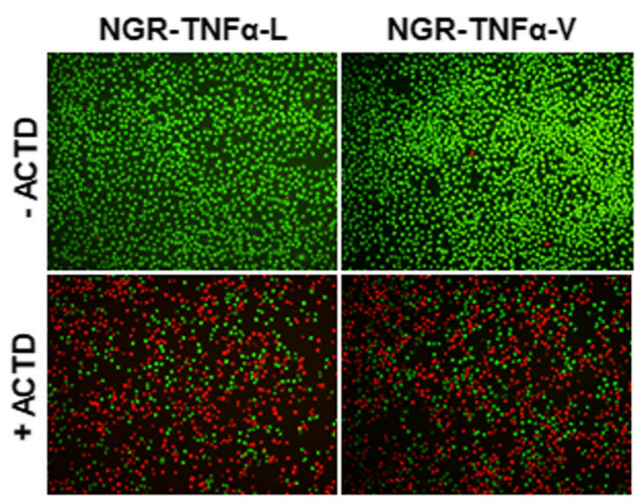

TNFa-L

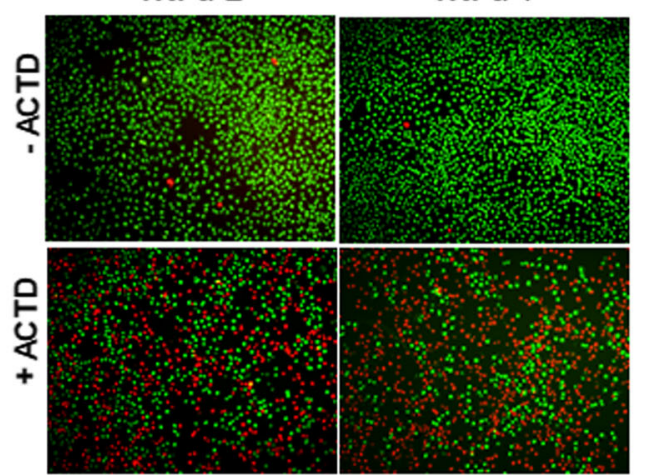

TNFa-V

C

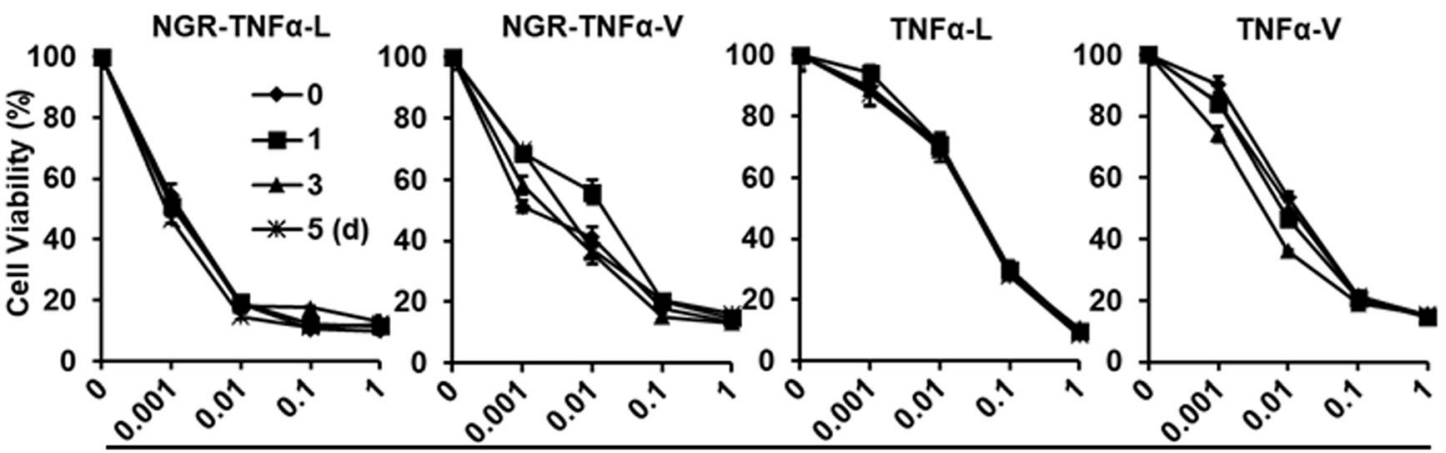

Protein Concentration (ng/mL)

Fig. 7 In vitro cytotoxicity of TNF $\alpha$ proteins. a,b Cytotoxicity of NGR-TNF $\alpha(\mathbf{a})$ and TNF $\alpha(\mathbf{b})$ proteins in L929 cells pretreated with or without ACTD for $30 \mathrm{~min}$ at $37^{\circ} \mathrm{C}$ prior to addition of proteins. c Cytotoxicity of TNF $\alpha$ proteins store at $37^{\circ} \mathrm{C}$ for different times $(0-5$ days $)$

Low-dose NGR-TNF $\alpha$ exerts synergistic antitumor effects with DOX (Corti et al. 2013). To evaluate the impact of the single amino acid substitution on the in vivo biological activity of NGR-TNF $\alpha$, the antitumor effects of NGR-TNF $\alpha-\mathrm{V}$ and NGR-TNF $\alpha$-L combined with DOX were compared in mice bearing B16F1 melanoma. As shown in Fig. 8, DOX exhibited antitumor effects in mice bearing B16F1 melanoma. Nevertheless, NGR-TNF $\alpha$-V and NGR-TNF $\alpha$-L alone only slightly suppressed tumor growth when compared to PBS. However, coadministration with either NGR-TNF $\alpha-\mathrm{V}$ or NGR-TNF $\alpha$-L significantly $(P<0.05)$ enhanced the antitumor effects of DOX. At the end of the observation, the average tumor volumes in NGR-TNF $\alpha-\mathrm{V} / \mathrm{DOX}$-treated mice and NGR-TNF $\alpha$-L/DOX-treated mice were $44.7 \pm 20.4 \mathrm{~mm}^{3}$ and $90.6 \pm 31.6 \mathrm{~mm}^{3}$, respectively, compared to $176 \pm 59.8$ $\mathrm{mm}^{3}$ for that of DOX-treated mice. The similarity between NGR-TNF $\alpha-\mathrm{V}$ and NGR-TNF $\alpha-\mathrm{L}$ in synergistic antitumor effects with DOX indicated that the single nucleotide mutation-induced amino acid substitution in TNF $\alpha$ did not reduce the biological activity of NGR-TNF $\alpha$.

\section{Discussion}

Although its systemic toxicity was reported a long time ago, $\mathrm{TNF} \alpha$, the most potent immune stimulator is still attractive for the development of novel anticancer therapeutics. Tumortargeted delivery is an effective way to reduce the systemic 

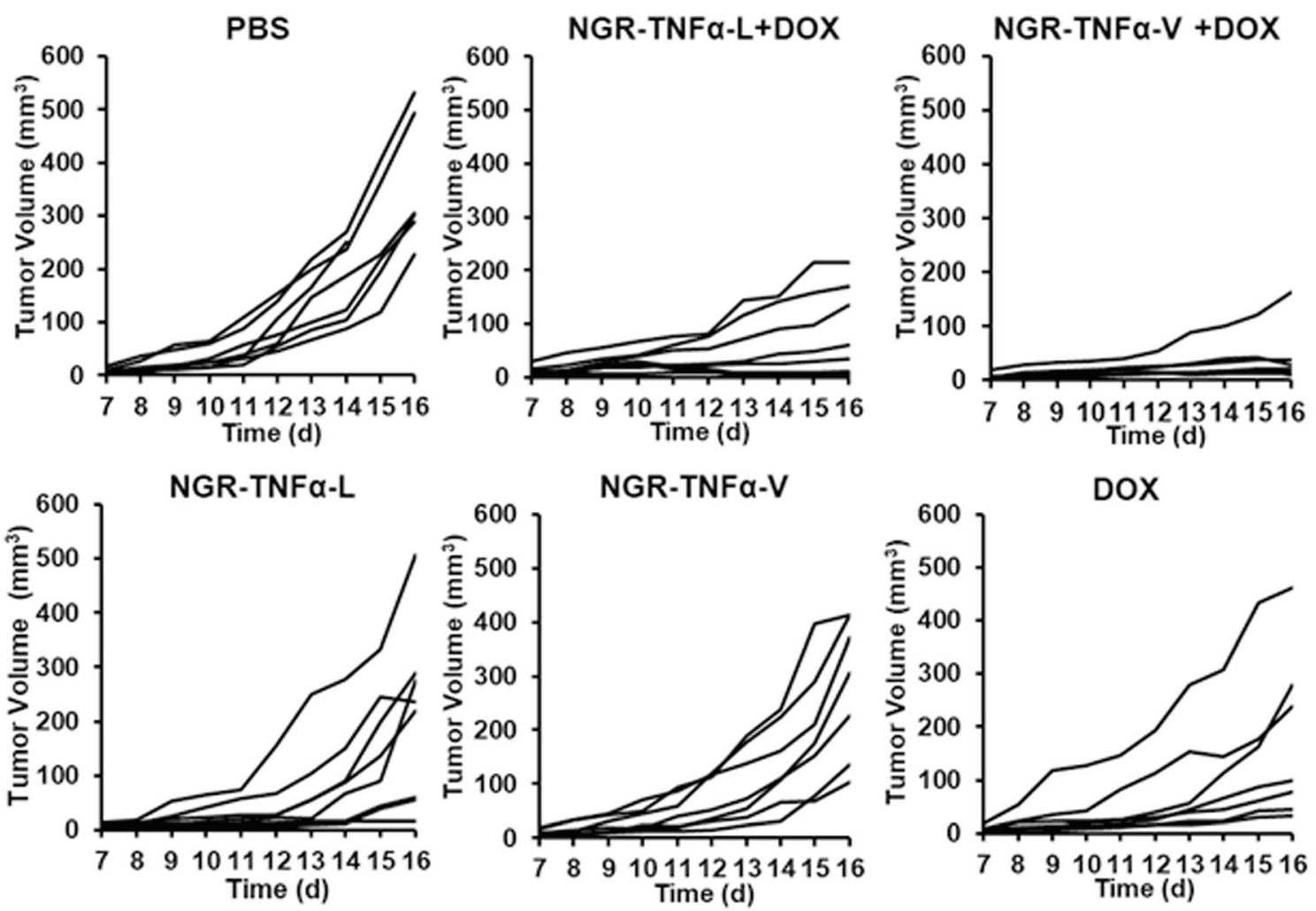

Fig. 8 In vivo antitumor effect of NGR-TNF $\alpha$ proteins combined with DOX. From day 7 postinoculation of B16F1 cells, TNF $\alpha$ protein $(1 \mu \mathrm{g} /$ mouse) and DOX ( $3 \mathrm{mg} / \mathrm{kg})$ were intravenously injected into mice every other day for a total of five injections. The perspective tumor growth curves were indicated

protein expression is primarily influenced by the protein solubility or gene sequence. Usually, the solubility of proteins can affect the expression level of genes in host cells. It was found that $\mathrm{TNF} \alpha$ was predominantly expressed as insoluble inclusion bodies in E. coli BL21 containing the pET plasmid with a strong T7 promoter. And it was noted that accumulation of inclusion bodies provided a negative feedback to the expression of TNF $\alpha$ (Binepal et al. 2012). In our experiment, TNF $\alpha$ and NGR-TNF $\alpha$ variants were predominantly expressed as soluble proteins in E. coli M15 containing the pQE30 plasmid with a weaker T5 promoter (Fig. 1 and 3), suggesting that the variation in expression of these TNF $\alpha$ proteins might not be attributed to the inclusion body accumulation-mediated negative feedback.

In addition to the protein properties, the sequence of the gene is closely related to its expression level in host cells. In the expression plasmid, elements, including the promoter, $5^{\prime}$ UTR, and initial codons of the recombinant gene, were the major impact factors for gene expression (Francis and Page 2010; Jia and Jeon 2016). In this paper, all TNF $\alpha$ and NGR$\mathrm{TNF} \alpha$ variants were cloned into the $\mathrm{pQE} 30$ plasmid. These expression plasmids containing TNF $\alpha$ or NGR-TNF $\alpha$ variants were only different $(C>G)$ in the initial codon of the $\mathrm{TNF} \alpha$ gene (Fig. 1a and 3a). The nucleotide mutation from $\mathrm{C}$ to $\mathrm{G}$ did not produce a rare codon (CUC to GUC) and had no 
influence on the translation of TNF $\alpha$ variants in E. coli. However, $\mathrm{G}$ at the $5^{\prime}$-end of a gene is more potent than $\mathrm{C}$ in that region in terms of impact on gene expression (Boel et al. 2016). Consequently, the variation of TNF $\alpha$ and NGR-TNF $\alpha$ variants in yield might be attributed to the alternation in transcription induced by the change of $\mathrm{C}$ to $\mathrm{G}$ in the initial codon of TNF $\alpha$. In fact, qRT-PCR demonstrated that the transcription of NGR-TNF $\alpha-\mathrm{V}$ with $\mathrm{G}$ in the initial codon of TNF $\alpha$ was higher than that of NGR-TNF $\alpha-\mathrm{L}$ with $\mathrm{C}$ in the initial codon. Similarly, the transcription of TNF $\alpha-\mathrm{V}$ was also higher than that of TNF $\alpha-\mathrm{L}$ (Fig. 4a and b). It is known that transcription and translation are coupled in the pQE30 plasmid with $\mathrm{T} 5$ promoter, which may affect transcription levels when the nucleotide mutation occurs at the 5 '-end of mRNA, presumably by premature transcription termination through the formation of secondary structures (Bhattacharyya et al. 2018; Stueber et al. 1984). The fact that the mutation of $C$ to $G$ in the initial codon of TNF $\alpha$ increased the yield of TNF $\alpha$ and NGR$\mathrm{TNF} \alpha$ variants by predominantly improving transcription in the $E$. coli M15-pQE30 system is consistent with the coupled transcription and translation in $\mathrm{pQE} 30$.

In the E. coli M15-pQE30 expression system, the yield of $\mathrm{TNF} \alpha$-L $(6.1 \pm 2.1 \mathrm{mg} / \mathrm{L})$ was higher than that of NGR$\mathrm{TNF} \alpha-\mathrm{L}(0.2 \mathrm{mg} / \mathrm{L})$, indicating that the $\mathrm{N}$-terminal fusion of NGR peptide reduced the expression of TNF $\alpha$-L in this system. However, both TNF $\alpha-\mathrm{V}$ and NGR-TNF $\alpha-\mathrm{V}$ were highly expressed in the same expression system, demonstrating that fusion of the NGR peptide to the N-terminus of TNF $\alpha-V$ had little impact on the yield of the fusion protein. Importantly, NGR-TNF $\alpha-\mathrm{V}$ was similar to NGR-TNF $\alpha$-L in receptorbinding (Fig. 6), in vitro cytotoxicity (Fig. 7), and in vivo antitumor effect (Fig. 8), suggesting that TNF $\alpha-\mathrm{V}$ might also be used to prepare novel tumor-homing TNF $\alpha$ variants. Taken together, our results demonstrated that a single nucleotide $\mathrm{C}>$ G mutation in the initial codon of TNF $\alpha$ drastically $(\sim 100$ times) increased the expression of NGR-TNF $\alpha$ in E. coli M15-pQE30 system by improving transcription. The single nucleotide $\mathrm{C}>\mathrm{G}$ mutation causing a substitution of leucine with valine at the start of TNF $\alpha$ had little impact on the biological activity of NGR-TNF $\alpha$, indicating that $\mathrm{TNF} \alpha$ with valine substitution at the start might be used to prepare novel tumor-homing $\mathrm{TNF} \alpha$ variant, especially when the native $\mathrm{TNF} \alpha$-based variant is expressed at an extremely low level in $E$. coli.

Supplementary Information The online version contains supplementary material available at https://doi.org/10.1007/s00253-021-11136-x.

Acknowledgment The authors thank Xijing Yang (Animal Center of West China Hospital, Sichuan University) for her help in animal experiments.

Author' contributions CJ and YH performed most experiments. FYR and SQX contributed to animal experiments. $\mathrm{LZ}$ and TZ purified proteins. FJ and LSF cultured cells. JYM extracted RNA. CJQ and LXF conceived this project. LXF, CJ, and YH wrote the paper, and all authors read and approved the manuscript.

Funding This study was funded by the National Natural Science Fund of China (81573336), the Key R\&D Program of Sichuan Province (2020YFS0072), the Special Project for COVID-19 of West China Hospital, Sichuan University (HX-2019-nCoV-018), and the "1.3.5 Project for Disciplines of Excellence, West China Hospital, Sichuan University" (ZYGD18014).

Data availability Data and materials will be made available on reasonable request.

\section{Compliance with ethical standards}

Conflict of interest The authors declare that they have no conflict of interest.

Ethical approval All applicable institutional guidelines for the care and use of animals were followed.

\section{References}

Balkwill F (2009) Tumour necrosis factor and cancer. Nat Rev Cancer 9(5):361-371. https://doi.org/10.1038/nrc2628

Bhattacharyya S, Jacobs WM, Adkar BV, Yan J, Zhang W, Shakhnovich EI (2018) Accessibility of the Shine-dalgarno sequence dictates Nterminal codon bias in E. coli. Mol Cell 70(5):894-905 e5. https:// doi.org/10.1016/j.molcel.2018.05.008

Binepal G, Ranjan RK, Rajagopal K (2012) Expression of synthetic human tumor necrosis factor is toxic to Escherichia coli. Gene 493(1): 155-160. https://doi.org/10.1016/j.gene.2011.11.025

Boel G, Letso R, Neely H, Price WN, Wong KH, Su M, Luff J, Valecha M, Everett JK, Acton TB, Xiao R, Montelione GT, Aalberts DP, Hunt JF (2016) Codon influence on protein expression in E. coli correlates with mRNA levels. Nature 529(7586):358-363. https:// doi.org/10.1038/nature16509

Corti A, Curnis F, Rossoni G, Marcucci F, Gregorc V (2013) Peptidemediated targeting of cytokines to tumor vasculature: the NGRhTNF example. BioDrugs 27(6):591-603. https://doi.org/10.1007/ s40259-013-0048-z

Curnis F, Sacchi A, Borgna L, Magni F, Gasparri A, Corti A (2000) Enhancement of tumor necrosis factor alpha antitumor immunotherapeutic properties by targeted delivery to aminopeptidase N (CD13). Nat Biotechnol 18(11):1185-1190. https://doi.org/10.1038/81183

Curnis F, Gasparri A, Sacchi A, Longhi R, Corti A (2004) Coupling tumor necrosis factor- $\alpha$ with $\alpha \mathrm{V}$ integrin ligands improves its antineoplastic activity. Cancer Res 64:565-571

Esquerre T, Laguerre S, Turlan C, Carpousis AJ, Girbal L, CocaignBousquet M (2014) Dual role of transcription and transcript stability in the regulation of gene expression in Escherichia coli cells cultured on glucose at different growth rates. Nucleic Acids Res 42(4): 2460-2472. https://doi.org/10.1093/nar/gkt1150

Fan Q, Tao Z, Yang H, Shi Q, Wang H, Jia D, Wan L, Zhang J, Cheng J, Lu X (2019) Modulation of pericytes by a fusion protein comprising of a PDGFRbeta-antagonistic affibody and TNFalpha induces tumor vessel normalization and improves chemotherapy. J Control Release 302:63-78. https://doi.org/10.1016/j.jconrel.2019.03.018

Francis DM, Page R (2010) Strategies to optimize protein expression in E. coli. Curr Protocols Protein Sci Chapter 5:Unit 5 24:1-29. https:// doi.org/10.1002/0471140864.ps0524s61 
Gopal GJ, Kumar A (2013) Strategies for the production of recombinant protein in Escherichia coli. Protein J 32(6):419-425. https://doi.org/ 10.1007/s10930-013-9502-5

Gregorc V, Santoro A, Bennicelli E, Punt CJ, Citterio G, Timmer-Bonte JN, Caligaris Cappio F, Lambiase A, Bordignon C, van Herpen CM (2009) Phase Ib study of NGR-hTNF, a selective vascular targeting agent, administered at low doses in combination with doxorubicin to patients with advanced solid tumours. Br J Cancer 101(2):219-224. https://doi.org/10.1038/sj.bjc.6605162

Ho YJ, Chu SW, Liao EC, Fan CH, Chan HL, Wei KC, Yeh CK (2019) Normalization of tumor vasculature by oxygen microbubbles with ultrasound. Theranostics 9(24):7370-7383. https://doi.org/10.7150/ thno. 37750

Hoffmann A, Müller MQ, Gloser M, Sinz A, Rudolph R, Pfeifer S (2010) Recombinant production of bioactive human TNF-alpha by SUMOfusion system-high yields from shake-flask culture. Protein Expr Purif 72(2):238-243

Hong S, Zheng DW, Zhang C, Huang QX, Cheng SX, Zhang XZ (2020) Vascular disrupting agent induced aggregation of gold nanoparticles for photothermally enhanced tumor vascular disruption. Sci Adv 6(23):eabb0020. https://doi.org/10.1126/sciadv.abb0020

Huang Y, Kim BYS, Chan CK, Hahn SM, Weissman IL, Jiang W (2018) Improving immune-vascular crosstalk for cancer immunotherapy. Nat Rev Immunol 18(3):195-203. https://doi.org/10.1038/nri. 2017.145

Jakob J, Hohenberger P (2016) Role of isolated limb perfusion with recombinant human tumor necrosis factor alpha and melphalan in locally advanced extremity soft tissue sarcoma. Cancer 122(17): 2624-2632. https://doi.org/10.1002/cncr.29991

Jia B, Jeon CO (2016) High-throughput recombinant protein expression in Escherichia coli: current status and future perspectives. Open Biol 6(8):160196. https://doi.org/10.1098/rsob.160196

Johansson A, Hamzah J, Payne CJ, Ganss R (2012) Tumor-targeted TNFalpha stabilizes tumor vessels and enhances active immunotherapy. Proc Natl Acad Sci U S A 109(20):7841-7846. https://doi.org/ 10.1073/pnas.1118296109

Kessler T, Baumeier A, Brand C, Grau M, Angenendt L, Harrach S, Stalmann U, Schmidt HL, Gosheger G, Hardes J, Andreou D, Dreischalück J, Lenz G, Wardelmann E, Mesters RM, Schwöppe C, Berdel WE, Hartmann W, Schliemann C (2018) Aminopeptidase $\mathrm{N}$ (CD13): expression, prognostic impact, and use as therapeutic target for tissue factor induced tumor vascular infarction in soft tissue sarcoma. Transl Oncol 11(6):1271-1282

Lugano R, Ramachandran M, Dimberg A (2020) Tumor angiogenesis: causes, consequences, challenges and opportunities. Cell Mol Life Sci 77(9):1745-1770. https://doi.org/10.1007/s00018-019-03351-7
Nouaille S, Mondeil S, Finoux AL, Moulis C, Girbal L, CocaignBousquet M (2017) The stability of an mRNA is influenced by its concentration: a potential physical mechanism to regulate gene expression. Nucleic Acids Res 45(20):11711-11724. https://doi.org/ 10.1093/nar/gkx781

Park JS, Kim IK, Han S, Park I, Kim C, Bae J, Oh SJ, Lee S, Kim JH, Woo DC, He Y, Augustin HG, Kim I, Lee D, Koh GY (2017) Normalization of tumor vessels by Tie2 activation and Ang2 inhibition enhances drug delivery and produces a favorable tumor microenvironment. Cancer Cell 31(1):157-158. https://doi.org/10. 1016/j.ccell.2016.12.009

Siemann DW (2011) The unique characteristics of tumor vasculature and preclinical evidence for its selective disruption by tumor-vascular disrupting agents. Cancer Treat Rev 37(1):63-74. https://doi.org/ 10.1016/j.ctrv.2010.05.001

Stueber D, Ibrahimi I, Cutler D, Dobberstein B, Bujard H (1984) A novel in vitro transcription-translation system: accurate and efficient synthesis of single proteins from cloned DNA sequences. EMBO J 3(13):3143-3148

Viallard C, Larrivee B (2017) Tumor angiogenesis and vascular normalization: alternative therapeutic targets. Angiogenesis 20(4):409 426. https://doi.org/10.1007/s10456-017-9562-9

Yang H, Wan L, Li X, Cai H, Chen L, Li S, Li Y, Cheng J, Lu X (2007) High level expression of his-tagged colicin 5 in E. coli and characterization of its narrow-spectrum bactericidal activity and poreforming action. Protein Expr Purif 54(2):309-317. https://doi.org/ 10.1016/j.pep.2007.03.006

Yehya AHS, Asif M, Petersen SH, Subramaniam AV, Kono K, Majid A, Oon CE (2018) Angiogenesis: managing the culprits behind tumorigenesis and metastasis. Medicina (Kaunas) 54(1):8. https://doi.org/ 10.3390/medicina54010008

Yuan X, Lin X, Manorek G, Kanatani I, Cheung LH, Rosenblum MG, Howell SB (2009) Recombinant CPE fused to tumor necrosis factor targets human ovarian cancer cells expressing the claudin- 3 and claudin-4 receptors. Mol Cancer Ther 8(7):1906-1915. https://doi. org/10.1158/1535-7163.MCT-09-0106

Zhou K, Zhou L, Lim Q, Zou R, Stephanopoulos G, Too HP (2011) Novel reference genes for quantifying transcriptional responses of Escherichia coli to protein overexpression by quantitative PCR. BMC Mol Biol 12:18. https://doi.org/10.1186/1471-2199-12-18

Zuazo-Gaztelu I, Casanovas O (2018) Unraveling the role of angiogenesis in cancer ecosystems. Front Oncol 8:248. https://doi.org/10. $3389 /$ fonc. 2018.00248

Publisher's note Springer Nature remains neutral with regard to jurisdictional claims in published maps and institutional affiliations. 